\title{
IMPLEMENTASI UNDANG-UNDANG NOMOR 11 TAHUN 2010 TERHADAP PELESTARIAN BENDA CAGAR BUDAYA DI KECAMATAN AMBARAWA KABUPATEN SEMARANG
}

\author{
Ratna Herawati ${ }^{1}$
}

\begin{abstract}
Abstrak
Benda cagar budaya merupakan kekayaan budaya Bangsa Indonesia yang penting artinya bagi pemahaman dan pengembangan sejarah, ilmu pengetahuan, dan kebudayaan. Benda cagar budaya perlu dilindungi dan dilestarikan demi pemupukan kesadaran jati diri dan kepentingan nasional. Oleh karena itu, untuk menjaga kelestarian benda cagar budaya diperlukan langkah pengaturan, yaitu dalam Undang-Undang Nomor 11 Tahun 2010 tentang Cagar Budaya. Salah satu letak benda cagar budaya ada di Kabupaten Semarang Kecamatan Ambarawa. Kecamatan Ambarawa. Beberapa obyek yang letaknya tersebar dan sudah cukup terkenal, antara lain Museum Kereta Api, Monument Palagan Ambarawa, dan Candi Gedong Songo. Berkaitan dengan Undang-Undang Nomor 11 Tahun 2010, maka akan ditinjau bagaimana implementasi undang-undang tersebut di Kecamatan Ambarawa Kabupaten Semarang serta apa saja kendala yang dihadapi. Adapun pendekatan yang digunakan dengan yuridis normatif. Pelestarian benda cagar budaya di Kecamatan Ambarawa Kabupaten Semarang telah sesuai dengan Undang-Undang Nomor 11 Tahun 2010. Adapun dinas daerah yang melaksanakan konservasi adalah dinas pendidikan dan kebudayaan. Hal ini dapat dilihat dari Peraturan Daerah Nomor 10 Tahun 2013. Kendala yang dihadapi berkaitan dengan sumber daya manusia, anggaran, sinkronisasi peraturan, dan partisipasi masyarakat.
\end{abstract}

Kata Kunci: Pelestarian benda cagar budaya, implementasi di Kecamatan Ambarawa Kabupaten Semarang, Undang-Undang Nomor 11 Tahun 2010.

\begin{abstract}
Objects of cultural heritage is a wealth of cultural nation of Indonesia that is important to the understanding and development of history, science, and culture. Objects of cultural heritage needs to be protected and preserved for fertilization awareness of identity and national interests. Therefore, to preserve the cultural heritage objects required regulatory measures, namely in Law Number 11 Year 2010 on Heritage. One of the objects of cultural heritage lies in Semarang Regency Ambarawa Subdistrict. Several objects that are dispersed and are well known, such as the Railway Museum, Monument Ambarawa, and Gedong Songo. Relating to Law No. 11 of 2010, it will be reviewed how the implementation of these laws in the Semarang Regency Ambarawa Subdistrict as well as any obstacles encountered. The approach used by the normative. Preservation of cultural heritage objects in the Semarang Regency Ambarawa Subdistrict in accordance with Law No. 11 of 2010. The local agencies that implement conservation is education and culture department. It can be seen from the Regional Regulation No. 10 of 2013. Obstacles encountered with regard to human resources, budget, synchronization rules, and community participation.
\end{abstract}

Keywords: Preservation of cultural heritage objects, implementation in District Ambarawa Semarang regency, Law Number 11 Year 2010

\footnotetext{
${ }^{1}$ Dosen Fakultas Hukum Universitas Diponegoro Semarang. Ratna_h27@Yahoo.com
} 


\section{A. Pendahuluan}

\section{Latar Belakang}

Bangsa Indonesia merupakan bangsa yang berbudaya tinggi dan budaya tersebut bernilai bagi peradaban. Negara harus menghargai, melindungi, melestarikan, dan mengembangkan kebudayaan nasional. Benda cagar budaya merupakan kekayaan budaya bangsa sehingga diperlukan langkah pengaturan bagi penguasaan, pemilikan, penemuan, pencarian, perlindungan, pemeliharaan, pengelolaan, pemanfaatan, dan pengawasan. Oleh karena itu diatur dalam Undang-Undang Nomor 11 Tahun 2010 tentang Cagar Budaya.

Undang-undang nomor 11 Tahun 2010 tentang Cagar Budaya, mengatur bahwa yang dimaksud benda cagar budaya adalah benda alam dan/atau benda buatan manusia, baik bergerak maupun tidak bergerak, berupa kesatuan atau kelompok, atau bagian-bagiannya, atau sisa-sisanya yang memiliki hubungan erat dengan kebudayaan dan sejarah perkembangan manusia. Adapun kriteria benda cagar budaya dilihat dari segi umur (50 tahun atau lebih), nilai tampilan, dan nilai sejarah. Hal ini diatur dalam Pasal 5 dan Pasal 6 Undang-Undang nomor 11 Tahun 2010. Lebih lanjut secara tegas dan jelas, Undangundang cagar budaya juga menyebutkan perlindungan benda cagar budaya bertujuan melestarikan dan memanfaatkannya untuk memajukan kebudayaan nasional Indonesia.
Dengan demikian benda cagar budaya merupakan salah satu cagar budaya, yang perlu dilestarikan keberadaannya karena memiliki nilai penting bagi sejarah, ilmu pengetahuan, pendidikan, agama, dan/atau kebudayaan melalui proses penetapan

Salah satu benda cagar budaya ada di Kecamatan Ambarawa Kabupaten Semarang. Beberapa obyek yang letaknya tersebar dan sudah cukup terkenal, antara lain Museum Kereta Api, Monument Palagan Ambarawa, dan Candi Gedong Songo.

Kecamatan Ambarawa merupakan salah satu dari 16 Kecamatan yang ada di Kabupaten Semarang. Wilayah ini diapit oleh dua gunung besar yakni Gunung Ungaran dan Gunung Telomoyo serta terletak di jalur jalan raya Semarang Yogyakarta. Letak astronomi Kecamatan Ambarawa terletak diantara $110^{\circ} 19^{\prime} 30^{\prime \prime} \mathrm{BT}$ - 110²6 30” BT dan $7^{\circ} 11^{\prime} 00^{\prime \prime}$ LS $7^{\circ} 17^{`} 30^{\prime \prime}$ LS. Selain itu Kecamatan Ambarawa terdiri dari 16 desa atau Kelurahan dan mempunyai luas secara keseluruhan 5612,46 Ha. Desa terluas adalah Desa Candi sedangkan desa yang terkecil adalah Desa Kranggan. Jarak dari pusat pemerintahan desa dengan pusat pemerintahan kecamatan cukup beragam. Yang terdekat adalah Desa Ambarawa karena pusat pemerintahan kecamatan ada di situ. Yang terjauh adalah Desa Candi yakni $12 \mathrm{Km}$. 
Selama ini terjadi kecenderungan pemanfaatan situs purbakala telah berjalan melebihi usaha pelestariannya. Salah satu contoh yaitu adanya camping ground di kompleks Candi Gedongsongo yang mampu menyedot pengunjung untuk berkemah disana. Akibatnya, terjadi kasus perusakan candi berupa pengguratan batu candi dengan benda tajam yang diduga dilakukan pengunjung. Di sisi lain pihak pemerintah Kabupaten Semarang telah melakukan gerakan menanam seribu pohon di kompleks Candi Gedongsongo untuk mendukung pelestarian alam di lingkungan candi. Oleh karena itu pelestarian benda cagar budaya di seluruh tanah air perlu melibatkan segenap komponen masyarakat.

\section{Perumusan Masalah}

Berdasarkan latar belakang tersebut, berikut ini beberapa permasalahan dalam penulisan ini:

1. Bagaimanakah implementasi UndangUndang Nomor 11 Tahun 2010 terhadap pelestarian benda cagar budaya di Kecamatan Ambarawa Kabupaten Semarang?

2. Kendala apasajakah yang dihadapi dalam implementasi Undang-Undang Nomor 11 Tahun 2010 terhadap pelestarian benda cagar budaya di Kecamatan Ambarawa Kabupaten Semarang?

\section{Tujuan dan Manfaat}

Tujuan penulisan ini adalah

a. Menganalisis mengenai implementasi Undang-Undang Nomor 11 Tahun 2010 terhadap pelestarian benda cagar budaya di Kecamatan Ambarawa Kabupaten Semarang.

b. Mendapatkan informasi mengenai kendala implementasi Undang-Undang Nomor 11 Tahun 2010 terhadap pelestarian benda cagar budaya di Kecamatan Ambarawa Kabupaten Semarang.

Penulisan ini diharapkan mampu memberikan manfaat antara lain

a. Memberikan informasi bagi Pemerintah Kabupaten Semarang tentang permasalahan implementasi UndangUndang No 11 Tahun 2010 terhadap pelestarian benda cagar budaya di Kecamatan Ambarawa Kabupaten Semarang.

b. Memberikan saran-saran yang dapat ditindaklanjuti berkaitan dengan implementasi Undang-Undang Nomor 11 Tahun 2010 terhadap pelestarian benda cagar budaya bagi Kabupaten dan Kota di Jawa Tengah untuk menghindari kendala-kendala yang hampir sama. 


\section{B. Tinjauan Pustaka}

Pelestarian adalah upaya dinamis untuk mempertahankan keberadaan Cagar Budaya dan nilainya dengan cara melindungi, mengembangkan, dan memanfaatkannya ( Pasal 1 angka 22 UU No. 11 Tahun 2010 tentang Cagar Budaya).

\section{Perlindungan Hukum}

Perlindungan hukum adalah upaya untuk melindungi subjek hukum dengan memberikan pengakuan dan jaminan atas hak-hak asasi subjek hukum . Perlindungan hukum $^{2}$ adalah pengakuan dan jaminan yang diberikan oleh hukum dalam hubungannya dengan hak-hak manusia. Esensi dari pengertian tersebut bahwasanya perlindungan hukum merupakan sebuah pengakuan dan jaminan dari hukum untuk melindungi subjek hukum akan hakhaknya. Philiphus M. Hadjon membagi perlindungan hukum ke dalam dua macam yaitu:

a. Perlindungan Hukum Preventif

Pada perlindungan hukum preventif ini, subjek hukum diberikan kesempatan untuk mengajukan keberatan atau pendapatnya sebelum suatu keputusan pemerintah mendapat bentuk yang definitif. Tujuannya adalah mencegah terjadinya sengketa. Perlindungan hukum preventif sangat besar artinya bagi tindak

\footnotetext{
2 Philiphus M. Hadjon , 1987, Perlindungan Hukum Bagi Rakyat Indonesia. Surabaya: Bina Ilmu, hal 83-84
}

pemerintahan yang didasarkan pada kebebasan bertindak karena dengan adanya perlindungan hukum preventif pemerintah terdorong untuk bersifat hati-hati dalam mengambil keputusan yang didasarkan pada diskresi.

b. Perlindungan Hukum Represif

Perlindungan hukum yang represif bertujuan untuk menyelesaikan sengketa. Penanganan perlindungan perlindungan hukum oleh Pengadilan Umum dan Pengadilan Administrasi di Indonesia termasuk kategori perlindungan hukum ini. Prinsip perlindungan hukum terhadap tindakan pemerintah bertumpu dan bersumber dari konsep tentang pengakuan dan perlindungan terhadap hak-hak asasi manusia karena menurut sejarah dari barat, lahirnya konsep-konsep tentang pengakuan dan perlindungan terhadap hak-hak asasi manusia diarahkan kepada pembatasanpembatasan dan peletakan kewajiban masyarakat dan pemerintah. Prinsip kedua yang mendasari perlindungan hukum terhadap tindak pemerintahan adalah prinsip negara hukum. Dikaitkan dengan pengakuan dan perlindungan terhadap hakhak asasi manusia mendapat tempat utama dan dapat dikaitkan dengan tujuan dari negara hukum.

Dalam kamus besar bahasa Indonesia perlindungan berasal dari kata lindung yang memiliki arti mengayomi, mencegah, mempertahankan, dan membentengi. Sedangkan perlindungan 
berarti konservasi, pemeliharaan, penjagaan, asilun, dan bunker. Indonesia sebagai negara hukum yang berdasarkan Pancasila harus memberikan perlindungan hukum terhadap masyarakat sesuai normanorma yang terdapat dalam Pancasila. Dengan demikian, perlindungan hukum memiliki dua esensi yaitu pengakuan dan jaminan akan hak-hak asasi.

Perlindungan terhadap cagar budaya yang diatur dalam Undang-Undang Nomor 11 Tahun 2010 Pasal 1 angka 23 yaitu perlindungan adalah upaya mencegah dan menanggulangi dari kerusakan, kehancuran, atau kemusnahan, dengan cara Penyelamatan, Pengamanan, Zonasi, Pemeliharaan, dan Pemugaran Cagar Budaya. Perlindungan hukum terhadap cagar budaya memiliki dua bentuk yakni perlindungan secara preventif yaitu berupa tindakan pencegahan, dan perlindungan restoratif yang berupa pemugaran cagar budaya. Cagar budaya juga memiliki hak untuk dilindungi demi kepentingan generasi bangsa yang sekarang maupun yang akan datang. Dengan demikian, arti perlindungan di dalam Undang-Undang Nomor 11 Tahun 2010 adalah mengenai objek fisik cagar budaya, sebagaimana Keputusan Menteri Republik Indonesia Nomor 063/U/1995 tentang Perlindungan dan Pemeliharaan Benda Cagar Budaya, perlindungan fisik dilakukan karena adanya ancaman proses alam dan dilakukan melalui kegiatan pemeliharaan (preservation), konservasi (conservation), dan pemugaran (restoration). Perlindungan hukum terhadap cagar budaya adalah setiap kegiatan yang dilakukan oleh pemerintah dalam melestarikan cagar budaya dengan memberikan pengakuan dan jaminan terhadap cagar budaya agar dapat bermanfaat bagi kegiatan ilmiah, keagamaan, maupun pariwisata. Sehingga cagar budaya dapat dipertahankan keberadaannya, dikembangkan, dan dimanfaatkan potensinya untuk kesejahteraan rakyat.

\section{Cagar Budaya}

Cagar budaya merupakan salah satu kekayaan bangsa yang penting keberadaannya karena mengandung nilainilai yang menunjukkan sejarah dan jati diri bangsa. Cagar budaya lahir karena hasil aktivitas manusia yang dilakukan pada zaman dahulu dan diwariskan dari generasi ke generasi. Jadi cagar budaya adalah warisan yang harus dijaga kelestariannya karena fungsinya yang sangat penting untuk menunjukkan identitas dan kepribadian bangsa.

Selain itu, cagar budaya tidak dapat diperbaharui dan kualitasnya semakin menurun seiring dengan pertambahan usia cagar budaya, serta berbagai faktor yang bersifat merusak seperti bencana alam dan ulah manusia yang tidak bertanggung jawab. Hal inilah yang menjadi dasar bahwa cagar budaya harus mendapatkan 
perlindungan hukum oleh pemerintah yang ditegaskan dengan dibentuknya UndangUndang Nomor 11 Tahun 2010 tentang Cagar Budaya.

Cagar budaya bersifat kebendaan dan memiliki wujud fisik yang bisa berupa benda, bangunan, struktur, situs, dan kawasan yang terletak di darat maupun di air. Pengertian cagar budaya di dalam Pasal 1 angka 1 Undang-Undang Nomor 11 Tahun 2010 yaitu "Cagar budaya adalah warisan budaya bersifat kebendaan berupa Benda Cagar Budaya, Bangunan Cagar Budaya, Struktur Cagar Budaya, Situs Cagar Budaya, dan Kawasan Cagar Budaya di darat dan/atau di air yang perlu dilestarikan keberadaannya karena memiliki nilai penting bagi sejarah, ilmu pengetahuan, pendidikan, agama, dan/atau kebudayaan melalui proses penetapan". Dengan demikian upaya untuk melestarikan cagar budaya tidak bisa dipandang sebelah mata.

Harus ada langkah konkrit dari pemerintah untuk memberikan perlindungan hukum terhadap cagar budaya agar dapat lestari serta bermanfaat bagi kegiatan ilmiah, penelitian, dan keagamaan. Dan yang terpenting cagar budaya digunakan untuk kepentingan bangsa dan kemakmuran rakyat.

\section{METODE PENELITIAN}

\section{Metode Pendekatan}

Peninjauan terhadap implementasi Undang-Undang No. 11 Tahun 2010 terhadap Pelestarian Benda Cagar Budaya di Kecamatan Ambarawa Kabupaten Semarang dengan pendekatan yuridis normatif. Pendekatan yuridis normatif memandang hukum sebagai peraturan perundang-undangan. Pendekatan yuridis normatif dimulai dengan menganalisa Undang-Undang No. 11 Tahun 2010 yang berkaitan dengan pokok permasalahan, hingga implementasi Undang-Undang No. 11 Tahun 2010 terhadap Pelestarian Bangunan Cagar Budaya di Kecamatan Ambarawa Kabupaten Semarang.

\section{Spesifikasi Penelitian}

Penelitian ini mempunyai spesifikasi sebagai penelitian deskriptif analitis. Bersifat deskriptif karena penelitian ini mempunyai maksud untuk memberikan gambaran secara rinci, sistematis dan meyeluruh mengenai segala sesuatu yang berhubungan dengan penelitian ini sedangkan analitis mengandung maksud mengelompokkan, menghubungkan, membandingkan dan memberi makna.

\section{Teknik Pengumpulan Data}

Data merupakan sesuatu yang diketahui atau yang dianggap berguna untuk mengetahui atau memperoleh 
gambaran suatu keadaan atau persoalan. ${ }^{3}$ Data yang digunakan dalam penelitian ini didapatkan dari kepustakaan (data sekunder). Berdasarkan hal tersebut maka data sekunder meliputi

1. Bahan Hukum Primer, merupakan bahan-bahan hukum yang mengikat, terdri dari:

- Peraturan Dasar yaitu Pasal 28C ayat (1) Undang-Undang Dasar Negara Republik Indonesia Tahun 1945.

- Peraturan Perundang-undangan

1. Undang-Undang Nomor 5 Tahun 1992 tentang Benda Cagar Budaya jo UndangUndang Nomor 11 Tahun 2010 tentang Cagar Budaya.

2. Undang-Undang Nomor 23 Tahun $2014 \quad$ tentang Pemerintahan Daerah.

3. Peraturan Menteri Kebudayaan dan Pariwisata No. PM.57/PW.007/MKP/2010.

4. Peraturan Menteri Pendidikan dan Kebudayaan Nomor 28 Tahun 2013 tentang Organisasi dan Tata Kerja Balai Pelestarian Cagar Budaya.

5. Peraturan Daerah Provinsi Jawa Tengah No. 10 Tahun 2013 tentang Pelestarian dan Pengelolaan Cagar Budaya.

3 M.Musa dan Titi Nurfitri, 1988, Metode Penelitian, Jakarta: Fajar Agung, hal 35.
6. Peraturan Daerah Kabupaten Semarang Nomor 10 Tahun 2013 tentang Organisasi dan Tata Kerja Dinas.

7. Peraturan Bupati Semarang Nomor 90 Tahun 2011 tentang Tugas, Pokok Fungsi, dan Rincian Tugas Dinas Daerah Kabupaten Semarang

2. Bahan Hukum Sekunder yang memberikan penjelasan mengenai bahan hukum primer dan dapat membantu memahami atau menganalisis bahan hukum primer yang berbentuk:

- buku-buku ilmiah yang berkaitan dengan bangunan cagar budaya,

- hasil-hasil penelitian yang berkaitan dengan penelitian, dan

- berbagai makalah, hasil seminar, majalah, jurnal ilmiah dan surat kabar yang berkaitan dengan penelitian.

\section{Teknik Pengolahan Data}

Setelah data terkumpul, data tersebut masih berupa bahan yang belum bisa memberikan arti apa-apa dan belum dapat ditarik kesimpulan. Oleh karena itu perlu diadakan usaha untuk mengolahnya. Proses pengolahan yang dilakukan peneliti adalah

a. Editing, yaitu pemeriksaan terhadap data yang diperoleh agar dapat dipertanggungjawabkan sesuai dengan 
kenyataan. Dalam proses ini peneliti melengkapi data yang belum lengkap.

b. Coding, yaitu mengklasifikasikan jawaban-jawaban narasumber menurut macamnya dengan jalan masingmasing jawaban diberi tanda atau kode tertentu; dan

c. Aplikasi, yaitu menerapkan data yang diperoleh dan diklasifikasikan dalam sub-sub bab tulisan.

\section{Analisis Data}

Teknik yang dipergunakan untuk menganalisis data dalam penelitian ini adalah metode analisis kualitatif yaitu pengkajian data berupa tulisan bukan data berupa angka. Dalam teknik ini, data yang telah diolah dikumpulkan, didentifikasi, dihubungkan, dan dianalisa sehingga menjadi data yang akurat dan disusun secara sistemtis. Hasil dari penelitian ini akan disampaikan atau ditampilkan dalam bentuk paparan atau tabel untuk selanjutnya disusun sebuah laporan penelitian.

\section{HASIL DAN PEMBAHASAN}

\section{Pelestarian Benda Cagar Budaya Di} Kecamatan Ambarawa Kabupaten

\section{Semarang}

Pelaksana atau penyelenggara pelestarian benda cagar budaya di kecamatan Ambarawa kabupaten Semarang pada tingkat provinsi diselenggarakan oleh Badan Pelestarian Peninggalan Purbakala (BP3) yang kemudian menjadi Balai
Pelestarian Cagar Budaya (BPCB) Jawa Tengah yang berada di Klaten. Balai Pelestarian Cagar Budaya (BPCB) Jawa Tengah merupakan salah satu Unit Pelayanan Teknis (UPT) dari Dinas Kebudayaan dan Pariwisata. Wilayah kerja dari Balai Pelestarian Cagar Budaya (BPCB) Jawa Tengah meliputi seluruh provinsi Jawa Tengah yang terdiri atas 29 Kabupaten dan 6 Kota.

\section{Balai Pelestarian Cagar Budaya} (BPCB) mempunyai tugas melaksanakan: pemeliharaan, perlindungan, pemugaran, dokumentasi, bimbingan dan penyuluhan, penyelidikan dan pengamanan terhadap peninggalan purbakala bergerak maupun tidak bergerak serta situs, termasuk yang berada dilapangan maupun tersimpan di ruangan. Struktur Organisasi Direktorat Jenderal Sejarah dan Purbakala, terbagi menjadi lima Direktorat, yakni :Direktorat Geografi Sejarah; Direktorat Nilai Sejarah; Direktorat Peninggalan Purbakala; Direktorat Museum; dan Direktorat Peninggalan Bawah Air. Kelima Direktorat tersebut memiliki Unit Pelaksana Teknis (UPT) untuk melaksanakan tugas pokok dan fungsi masing-masing, sedangkan susunan organisasi BPCB Jawa Tengah itu sendiri terdiri dari Kepala; Sub Bagian Tata Usaha; Seksi Pelestarian dan Pemanfaatan; dan Kelompok Jabatan Fungsional.

$$
\text { Penyelenggaraan kegiatan }
$$
pelestarian benda cagar budaya pada Kabupaten Semarang berdasarkan 
Peraturan Daerah No.10 Tahun 2013 tentang Perubahan Kedua Atas Peraturan Daerah Kabupaten Semarang Nomor 18 Tahun 2008 Tentang Organisasi Dan Tata Kerja Dinas Daerah Kabupaten Semarang, yaitu Dinas Pendidikan dan Kebudayaan. Adapun pelestarian benda cagar budaya masuk dalam Bidang Kebudayaan, yang membawahi Seksi Kesejarahan, Permuseuman, Dan Kepurbakalaan; dan Seksi Kesenian Dan Nilai-nilai Budaya. Namun dalam Peraturan Bupati Semarang Nomor 90 Tahun 2011 tentang Tugas, Pokok Fungsi, dan Rincian Tugas Dinas Daerah Kabupaten Semarang, pelestarian benda cagar budaya masih diselenggarakan oleh Dinas Pemuda, Olahraga, Kebudayaan, dan Pariwisata.

Implementasi UU No.11 Tahun 2010 tentang Cagar Budaya, pelestarian terdapat dalam Bab VII tentang Pelestarian.

\section{a) Perlindungan, pemeliharaan dan perawatan cagar budaya}

Setiap orang yang memiliki atau menguasai benda cagar budayawajib melindungi dan memeliharanya. Perlindungan dan pemeliharaan benda cagar budaya sebagaimana dimaksud dalam ayat (1) wajib dilakukan dengan memperhatikan nilai sejarah dan keaslian bentuk serta pengamanannya. Orang yang memiliki atau menguasai benda cagar budaya tertentu, yaitu: dimiliki atau dikuasai secara turun-temurun atau merupakan warisan; dan jumlah untuk setiap jenisnya cukup banyak dan sebagian telah dimiliki oleh Negara.

Pemerintah memberikan teguran apabila orang tersebut tidak melaksanakan kewajiban melindungi dan memelihara benda cagar budaya. Sejak dikeluarkan teguran dalam waktu 90 (sembilan puluh) hari, upaya perlindungan tetap tidak dilaksanakan oleh pemilik atau yang menguasai benda cagar budaya, Pemerintah dapat mengambil alih kewajiban untuk melindungi benda cagar budayayang bersangkutan.

Setiap orang dilarang merusak benda cagar budaya dan situs serta lingkungannya tanpa seizing pemerintah. Perusakkan tersebut antara lain:

a. membawa benda cagar budaya ke luar wilayah Republik Indonesia;

b. memindahkan benda cagar budaya dari daerah satu ke daerah lainnya;

c. mengambil atau memindahkan benda cagar budaya baik sebagian maupun seluruhnya, kecuali dalam keadaan darurat;

d. mengubah bentuk dan/atau warna serta memugar benda cagar budaya;

e. memisahkan sebagian benda cagar budaya dari kesatuannya;

f. memperdagangkan atau memperjualbelikan atau memperniagakanbenda cagar budaya. 
Pemerintah dapat menahan atau memerintahkan agar benda cagar budaya yang telah dibawa atau dipindahkan tanpa izin, dikembalikan ke tempat asal atas beban biaya orang yang membawa atau memindahkannya. Setiap kegiatan yang berkaitan dengan penetapan suatu lokasisebagai situs disertai dengan pemberian ganti rugi kepada pemilik tanah yangbersangkutan.

Perlindungan dan pemeliharaan benda cagar budaya di kabupaten Semarang dilaksanakan oleh Bidang Kebudayaan yaitu:

a. Seksi Nilai-nilai Budaya, yang memiliki rincian tugas, antara lain :

1) menyusun program kerja dan anggaran seksi nilai-nilai budaya;

2) melaksanakan fasilitasi, pembinaan, pengembangan, dan pelestarian nilai-nilai budaya, termasuk budaya spiritual;

3) memfasilitasi kegiatan kebudayaan antar kabupaten/kota.

b. Seksi Kesejarahan, Museum, dan Kepurbakalaan, yang memiliki rincian tugas, antara lain :

1) Menyusun program kerja dan anggaran seksi kesejarahan, museum dan kepurbakalaan

2) Memfasilitasi dan mengembangkan penulisan sejarah, antara lain melalui rekaman, penelitian, penulisaqn,

penanaman nilai-nilai, dan penyebaran informasi sejarah daerah

3) Menanamkan nilai-nilai sejarah daerah dan nasional melalui kegiatan-kegiatan kebudayaan dan kepariwisataan

4) Menyiapkan rekomendasi izin pemindahan benda cagar budaya dari kabupaten Semarang ke daerah lain

5) Menerima permohonan kepemilikan benda cagar budaya berdasarkan pedoman yang telah ditetapkan pemerintah.

Kewajiban dalam pemeliharaan cagar budaya sebagaimana diatur pada Bab VII Pasal 75 Undang-Undang Nomor 11 Tahun 2010 tentang Cagar Budaya, yaitu

1. Setiap orang wajib memelihara cagar budaya yang dimiliki dan/atau dikuasainya.

2. Cagar budaya yang ditelantarkan oleh pemilik dan/atau yang menguasainya dikuasai oleh Negara

Dengan demikian pemeliharaan terhadap cagar budaya tidak hanya dibebankan kepada pemerintah daerah atau pemerintah pusat saja, namun juga bagi setiap orang atau masyarakat yang memiliki atau menguasai cagar budaya wajib melakukan pemeliharaan terhadap cagar budaya.

Hal ini dikarenakan kepemilikan cagar budaya yang akhirnya diakui oleh 
pemerintah melalui Undang-Undang

Nomor 11 Tahun 2010 tentang Cagar Budaya. Namun demikian, apabila cagar budaya tersebut ditelantarkan atau tidak dipelihara oleh pemilik atau yang menguasainya, maka pemerintah merupakan pihak yang diutamakan untuk mengambil alih penguasaan atas cagar budaya tersebut.

Adapun perawatan cagar budaya diatur dalam Pasal 76 ayat (3), ayat (4), ayat (5), dan ayat (6) Undang-Undang Nomor 11 Tahun 2010 tentang Cagar Budaya. Perawatan cagar budaya adalah dengan melakukan pembersihan, pengawetan, dan perbaikan atas kerusakan dengan memperhatikan keaslian bentuk, tata letak, gaya, bahan, dan/atau teknologi cagar budaya. Dalam hal cagar budaya yang dikuasai oleh negara, perawatan cagar budaya dilakukan oleh BPCB (Balai Pelestarian Cagar Budaya) yang terdapat di setiap provinsi. Perawatan cagar budaya dilakukan setiap 4 (empat) tahun sekali dengan memperhatikan daftar prioritas yang mengacu pada pemeringkatan cagar budaya.

\section{b) Pengelolaan}

Pengelolaan benda cagar budaya di kabupaten Semarang dilaksanakan oleh Bidang Kebudayaan yaitu:

a. Seksi Nilai-nilai Budaya, yang memiliki rincian tugas pengelolaan, antara lain
1) Melaksanakan penggalian, penelitian, pengkajian penulisan, penanaman dan penyebarluasan informasi nilai-nilai budaya termasuk budaya spiritual

2) Melaksanakan monitoring dan evaluasi pelaksanaan kegiatan seksi nilai-nilai budaya

b. Seksi Kesejarahan, Museum dan Kepurbakalaan, yang memiliki rincian tugas pengelolaan, antara lain

1) Menyiapkan data pendukung pemetaan situs dan peninggalan sejarah dalam rangka inventarisasi dan pelestarian

2) Melaksanakan studi kelayakan dan studi teknis lokasi benda cagar budaya untuk bahan pengambilan kebijakan pengembangan serta upaya penyelamatan, pengamanan, pemeliharaan, pemugaran, penggalian, dan penelitian benda cagar budaya

3) Melaksanakan bimbingan dan penyuluhan dalam rangka peningkatan apresiasi dan peran serta masyarakat, terhadap upaya pelestarian peninggalan sejarah, dan benda cagar budaya

4) Melaksanakan konservasi kebudayaan 
5) Melaksanakan monitoring dan evaluasi pelaksanaan kegiatan seksi kesejarahan, museum, dan kepurbakalaan.

\section{c) Pemanfaatan}

Berdasarkan Peraturan Daerah

Provinsi Jawa Tengah Nomor 10 Tahun 2013 tentang Pelestarian dan Pengelolaan Cagar Budaya, bahwa pemanfaatan adalah pendayagunaan Cagar Budaya untuk kepentingan sebesar-besarnya kesejahteraan rakyat dengan tetap mempertahankan kelestariannya. Adapun Undang-Undang Nomor 11 Tahun 2010, pemanfaatan cagar budaya ditujukan bagi kepentingan sosial, pendidikan, pengembangan ilmu pengetahuan, agama, kebudayaan, dan/atau pariwisata. Pemanfaatan tersebut tidak dapat dilakukan dengan cara atau apabila :
a. bertentangan dengan upaya perlindungan benda cagar budaya;
b. semata-mata untuk mencari keuntungan pribadi dan/atau golongan.

Pemerintah dapat menghentikan kegiatan pemanfaatan benda cagar budaya apabila pelaksanaannya ternyata berlangsung dalam keadaan sebagaimana tersebut di atas.

Adapun peran pemerintah kabupaten/kota berdasarkan Perda Nomor 10 Tahun 2013 yaitu memfasilitasi pemanfaatan dan promosi Cagar Budaya yang dilakukan oleh setiap orang; memberikan izin pemanfaatan sesuai dengan peringkat Cagar Budaya dan/atau masyarakat hukum adat yang memiliki dan/atau menguasainya; menghentikan pemanfaatan atau membatalkan izin pemanfaatan Cagar Budaya apabila pemilik dan/atau yang menguasai terbukti melakukan perusakan atau menyebabkan rusaknya Cagar Budaya; bekerja sama dengan setiap orang dalam melakukan pendaftaran Cagar Budaya; menyampaikan hasil penetapan Cagar Budaya kepada pemerintah daerah Provinsi; melakukan pemeringkatan Cagar Budaya berdasarkan kepentingannya menjadi peringkat Nasional, peringkat Provinsi, dan peringkat Kabupaten/Kota berdasarkan rekomendasi Tim Ahli Cagar Budaya.

Apabila dibandingkan antara Perda Provinsi Jawa Tengah Nomor 10 Tahun 2013 tentang Pengelolaan dan Pelestarian Cagar Budaya dengan Peraturan Bupati Semarang Nomor 90 Tahun 2011 tentang Tugas, Pokok Fungsi, dan Rincian Tugas Dinas Daerah Kabupaten Semarang, maka terdapat perbedaan tugas dalam pengelolaan cagar budaya di Kabupaten Semarang. Peran Kabupaten/kota yang ada dalam perda Provinsi Jawa Tengah lebih luas daripada yang terjabarkan dalam Peraturan Bupati Semarang Nomor 90 Tahun 2011. Selain itu dalam Peraturan Bupati Semarang Nomor 90 Tahun 2011 tentang Tugas, Pokok Fungsi, dan Rincian Tugas Dinas Daerah Kabupaten Semarang, pelestarian benda cagar budaya masih 
diselenggarakan oleh Dinas Pemuda,

Olahraga,

Kebudayaan,

dan

Pariwisata.Adapun dengan diterbitkannya

PerdaKabupaten Semarang Nomor 10

Tahun 2013 tentang tentang Perubahan

Kedua Atas Peraturan Daerah Kabupaten

Semarang Nomor 18 Tahun 2008 Tentang

Organisasi Dan Tata Kerja Dinas Daerah

Kabupaten Semarang, yaitu Dinas

Pendidikan dan Kebudayaan. Adapun pengaturan lebih lanjut tentang pengelolaan dan pelestarian cagar budaya belum ditindaklanjuti dalam bentuk peraturan perundang-undangan oleh pemerintah Kabupaten Semarang.

2. Kendala dalam Implementasi Pelestarian

Pelestarian benda cagar budaya dapat dilakukan sendiri oleh kabupaten/kota yang ditemukan/terdapat benda cagar budaya (Kabupaten Semarang) dengan tetap memperhatikan asas desentralisasi antara Pemerintah sebagai penyandang dana, Pemerintah Provinsi sebagai penyandang dana, perlindungan dan pemeliharaan, pengelolaan, dan pemanfaatan pada tingkat Provinsi, serta Pemerintah Kabupaten/Kota sebagai unsur perlindungan dan pemeliharaan, pengelolaan, dan pemanfaatan pada tingkat kabupaten/kota.

Perlindungan dan pemeliharaan, pengelolaan, dan pemanfaatan yang dilaksanakan secara mandiri dan terkoordinasi secara vertikal dan horizontal oleh Pemerintah Daerah Kabupaten/kota akan mewujudkan pelestarian benda cagar budaya yang optimal dan berkesinambunagan untuk kesejahteraan masyarakat kabupaten/kota tersebut.

Pelaksanaan konservasi benda cagar budaya yang meliputi perlindungan dan pemeliharaan, pengelolaan, dan pemanfaatan tidak selamanya berjalan sesuai dengan yang diharapkan. Hal tersebut disebabkan adanya hambatanhambatan seperti :

a. Kurangnya koordinasi antara Pemerintah Kabupaten/Kota dengan pemerintah provinsi.

Dinas Pemuda, Olah Raga, Kebudayaan dan Pariwisata Kabupaten Semarang dengan Pemerintah Provinsi yang menyelenggarakan konservasi benda cagar budaya yakni Balai Pelestarian Cagar Budaya (BPCB) Jawa Tengah kurang berkoordinasi dalam hal pengelolaan dan pelestarian benda cagar budaya. Hal ini dikarenakan hanya ada satu Balai Pelestarian Cagar Budaya (BPCB) Jawa Tengah sedangkan wilayah kerja meliputi seluruh provinsi Jawa Tengah yang terdiri atas 29 Kabupaten dan 6 Kota.

b. Kurangnya informasi dan koordinasi yang dimiliki oleh Dinas-Dinas di lingkup Pemerintahan Kabupaten 
Semarang dalam rangka pengelolaan dan pelestarian benda cagar budaya.

c. Minimnya anggaran yang dimiliki Dinas Pemuda, Olah Raga, Kebudayaan dan Pariwisata Kabupaten Semarang untuk menyelenggarakan pelestarian benda cagar budaya di Kabupaten Semarang.

d. Adanya ketidaksinkronan antara peraturan perundang-undangan.

Implementasi Undang-Undaang Cagar Budaya yang ditindaklanjuti dengan peraturan perundangundangan dibawahnya ternyata tidak sinkron antara satu dengan lainnya. Hal ini berkaitan dengan peran kabupaten/kota dalam pengelolaan dan pelestarian benda cagar budaya, dan pelaksana pengelolaan benda cagar budaya di Kabupaten Semarang.

e. Kurangnya kesadaran masyarakat terhadap upaya konservasi benda cagar budaya di kecamatan Ambarawa Kabupaten Semarang.

Peran masyarakat dalam pelestarian cagar budaya merupakan implementasi dari asas partisipasi yang terkandung di dalam Pasal 2 Undang-Undang Cagar Budaya. Asas partisipasi adalah bahwa setiap anggota masyarakat didorong untuk berperan aktif di dalam pelestarian cagar budaya. Dengan demikan, masyarakat diharapkan memiliki kesadaran terhadap pentingnya melestarikan cagar budaya untuk kepentingan bangsa.

\section{E. SIMPULAN}

Berdasarkan pembahasan diatas dapat disimpulkan sebagai berikut :

1. Implementasi Undang-Undang Nomor 11 Tahun 2010 terhadap pelestarian benda cagar budaya di Kecamatan Ambarawa Kabupaten Semarang meliputi

a. Perlindungan, pemeliharaan dan perawatan cagar budaya

b. Pengelolaan

c. Pemanfaatan Implementasi tersebut belum berjalan optimal. Hal ini dikarenakan belum adanya peraturan daerah Kabupaten Semarang yang mengatur tentang cagar budaya di Kabupaten Semarang yang menjadi dasar hukum perlindungan terhadap cagar budaya.

2. Kendala dalam implementasi pelestarian:

a. Kurangnya koordinasi antara Pemerintah KabupatenSemarang dengan Pemerintah Provinsi Jawa Tengah

b. Kurangnya informasi dan koordinasi yang dimiliki oleh Dinas-Dinas di lingkup Pemerintahan Kabupaten Semarang 
c. Minimnya anggaran dalam pelestarian benda cagar budaya di Kabupaten Semarang

d. Adanya ketidaksinkronan antara peraturan perundang-undangan.

e. Kurangnya kesadaran masyarakat terhadap upaya konservasi benda cagar budaya di kecamatan Ambarawa Kabupaten Semarang.

\section{DAFTAR PUSTAKA}

M. Hadjon, Philiphus, Perlindungan Hukum Bagi Rakyat Indonesia. Surabaya: Bina Ilmu, 1987.

M.Musa dan Titi Nurfitri, Metode Penelitian, Jakarta: Fajar Agung, 1988.
Undang-Undang Nomor 5 Tahun 1992 tentang Benda Cagar Budaya jo Undang-Undang Nomor 11 Tahun 2010 tentang Cagar Budaya.

Undang-Undang Nomor 23 Tahun 2014 tentang Pemerintahan Daerah.

Peraturan Menteri Pendidikan dan Kebudayaan Nomor 28 Tahun 2013 tentang Organisasi dan Tata Kerja Balai Pelestarian Cagar Budaya.

Peraturan Daerah Provinsi Jawa Tengah No. 10 Tahun 2013 tentang Pelestarian dan Pengelolaan Cagar Budaya.

Peraturan Daerah Kabupaten Semarang Nomor 10 Tahun 2013 tentang Organisasi dan Tata Kerja Dinas.

Peraturan Bupati Semarang Nomor 90 Tahun 2011 tentang Tugas, Pokok Fungsi, dan Rincian Tugas Dinas Daerah Kabupaten Semarang. 